\title{
Technostress among marketing employee during the COVID-19 pandemic: Exploring the role of technology usability and presenteeism
}

\author{
Khuzaini $^{1}$, Zakky Zamrudi ${ }^{2 *}$ \\ ${ }^{1}$ Postgraduate Program, Universitas Islam Kalimantan Muhammad Arsyad Al Banjari \\ Banjarmasin, Banjarmasin, Indonesia \\ ${ }^{2}$ Department of Management, Faculty of Economics, Universitas Islam Kalimantan \\ Muhammad Arsyad Al Banjari Banjarmasin, Banjarmasin, Indonesia \\ *Corresponding Author(s) Email: zakky@uniska-bjm.ac.id
}

\section{ABSTRACT}

The COVID-19 pandemic is profoundly affecting the way of consumer buying. Firms are therefore challenged to be more reliant on technology as many consumers have turned into protection mode and do anything remotely. While the usage of technology has offered flexibility and simplicity, it has also exacerbated the technostress issue. This study was conducted to understand and examine technology usability and presenteeism that influence technostress during the COVID-19 pandemic situations. A five-point Likert scale questionnaire survey was used to evaluate the perceptions of technology characteristics and techno-stress among marketing employees. A total of 262 respondents that classified as marketing employees that are experienced "working from home" during the pandemic, were collected and analyzed by using Covariance Based Structural Equation Modeling (CB-SEM). The results suggest that technology usability has positive influences on techno-complexity and techno-insecurity. Moreover, the negative influences of presenteeism on technooverload and techno-insecurity were also proved in this study. Interestingly, marketing employees do not see their hyper-connectivity with technology implemented by the company impact their workloads and worries as they consider the current radical changes only temporary and will only last during the pandemic.

Keywords: Technostress; Techno-Invasion; TechnoOverload; Techno-Complexity; TechnoInsecurity; Usefulness; COVID-19
JEL Code:

M10, M12, C12

DOI:

10.31106/jema.v18i1.10050

Article History:

Received 2021-02-03

Reviewed 2021-03-08

Revised 2021-03-16

Accepted 2021-03-31

Licensed:

CC-BY 
Technostress among marketing employee during the COVID-19 pandemic: Exploring the role of technology usability and presenteeism by Khuzaini, Zakky Zamrudi

\section{Introduction}

The outbreak of the COVID-19 pandemic has hit the development of the global economy and produced a huge crisis to the survival of firms worldwide. Although the current COVID19 pandemic is not the first pandemic that has arisen globally, it is the first time that such a pandemic has had a global effect in a just few short weeks after World Health Organization (WHO) pandemic announcements (Brem et al., 2021). As a consequence, the implementation of lockdown and social distancing mandates by governments resulted in massive changes in consumer behavior as they have turned into protection mode, having more self-awareness (health concerns), and do anything remotely. Firms are therefore challenged to be relevant with this natural disruption and relied on the usages of technology to survive. With the outbreak of the COVID-19 pandemic, working from home has become a new mandatory habit as part of the public health responsibility. Raghuram et al. (2019) argue that the usage of technology or computer-mediated work (CMW) is expected to ease the process of information sharing among employees. Rupietta \& Beckmann (2018) and Zainuddin \& Isa (2019) added that working from home also could impact the increase of intrinsic motivation and information sharing activities.

While the usage of technology has offered productivity, efficiency, and flexibility, it has also exacerbated technostress problems in the workplace. Prior studies related to this phenomenon confirmed that technostress could become a significant factor in personal health problem, job dissatisfaction, work inefficiency, and ineffectiveness (Boonjing \& Chanvarasuth, 2017; Durucu \& Bayraktar, 2020; Hung et al., 2015; Mahboob, 2016; Tarafdar et al., 2007; Zulfany et al., 2019), unwillingness to extend the use of technology (Fuglseth \& Sørebø, 2014), the loss of career promotion (Cooper \& Kurland, 2002; Van Steenbergen et al., 2018) and customer dissatisfaction (Christ-Brendemühl \& Schaarschmidt, 2020). Moreover, Tarafdar et al. (2014) added that there is a potential conflict that could lead to stress due to the use of technology (technostress) among salespeople as many of them would rather spend time interact with consumers than in front of the computer screen (Geiger \& Turley, 2006; Rangarajan et al., 2005). Gschwandtner (2011) argued that the shifts in time spent priority of salespeople from selling to use of technology could affect into lost sales.

Technostress terminology was initially introduced in the medical field by Brod (1982), who defined it as the situation of overall stress in which experienced by an individual due to their inability to adapt to the new trend of technology in a healthy manner (Tarafdar et al., 2014). Technostress can be divided into four categories which consist of techno-invasion, 
techno-overload, techno-complexity, techno-insecurity, and techno-uncertainty (Tarafdar et al., 2007). Since then, many scholars have extended the critical aspects of technostress in a different point of view for example. Ayyagari et al. (2011) identified five aspects of technostress which is work overload, role ambiguity, invasion of privacy, work-home conflict, and job insecurity. Followed by Stich et al. (2017), Wang et al. (2020), and Zhang et al. (2016) that used attitude toward technology, workload, work complexity, digital literacy, user involvement, person-organization misfit, person-people misfit, and persontechnology enhanced learning (TEL) misfit as a multidimensional aspect that affecting the level of tecnostressors. Technostress has become a crucial issue especially in the crises like COVID-19 in which most people using technology to interact and continue their job responsibilities. The previous study related to the topic of technostress has occurred mostly during the "normal conditions". Therefore, it is essential to examine the potential stress caused by technology especially as the longitudinal study during the "normal conditions" (even before the COVID-19 pandemic) that's indicated a contradictory result (Ter Hoeven et al., 2016; Van Steenbergen et al., 2018).

Moreover, several recent studies confirmed the significant role of technology characteristics as the predictors of techcnostress. Ayyagari et al. (2011) stated that technology characteristics such as usability (usefulness, complexity, and reliability), intrusiveness (presenteeism, anonymity), and dynamism (pace of change) have a significant influence on technostress level. They also concluded that while work overload and role ambiguity found to be the two most dominant techostressors, intrusiveness characteristics were confirmed as the dominant predictors of techostress. Interestingly, although their study confirmed the significant contribution of usability in the level of technology adoption, Verkijika (2019) stated that in general, the association between usability and technology adoption is quite questionable as several studies found different results either not strong enough or nonsignificant. Furthermore, Zhao et al. (2020) added that presenteeism also can be classified as one of tehcnostress creators. With the presence of technology, employees are connected to their job even during their off-job time (hyper-connectivity). These situations therefore often viewed as significant obstacles to their personal growth and career promotion. This study aims to understand and examine the effect of technology usability and the presence of technology on techno-stress dimensions (such as techno-complexity, invasion, overload, and insecurity). This study advances the emerging of technostress discourse by including the role of hyper-connectivity as one of the technostress predictors during the COVID-19 pandemic situations 
Technostress among marketing employee during the COVID-19 pandemic: Exploring the role of technology usability and presenteeism by Khuzaini, Zakky Zamrudi

\section{Literature Review}

\section{Technostress in the Workplace}

The crucial role of technology usages in escalating the performance of a business is unavoidable. Dhomane \& Mathew (2021) even added that the COVID-19 pandemic crisis has fast-tracked the growth of technology usages like never before especially as the dependency of most people on technology to interact and continue their job responsibilities. Even though the usage of technology has offered productivity, efficiency, and flexibility, it is also surrounded by the difficulties to adapt to technological resources that were designed by the company. This paradoxical issue is known as (workplace) technostress which was first coined in the medical field by (Brod, 1982). While Chandra et al. (2019) defined workplace stress as a default response of employee regarding the onset pressure condition which is the misfit between job demand and the ability to meet those demands, technostress is the stress that suffered by employees due to the inability to cope up with technology (Khan et al., 2013; Nisafani et al., 2020; Yu et al., 2017).

Prior study related to technostress in the workplace shows the association of technostress on organization performances, productivity, satisfaction, career development, health and wellness, attitude toward technology, and job security (Atanasoff \& Venable, 2017; Boonjing \& Chanvarasuth, 2017; Christ-Brendemühl \& Schaarschmidt, 2020; Durucu \& Bayraktar, 2020; Fuglseth \& Sørebø, 2014; Hung et al., 2015; Mahboob, 2016; Tarafdar et al., 2011; Zulfany et al., 2019). Moreover, in the case of sales professionals, technology use is often seen as an additional stressor that could decrease their overall performance in the sales role (Tarafdar et al., 2014). Although most sales professionals have confidence in their technology self-efficacy, they will reject any initiatives of technology project due to their unwillingness to adopt that particular technology (Speier \& Venkatesh, 2002). A study from Ahearne \& Rapp (2010), confirmed that the usages of technology by sales employees could increase their stress level, job dissatisfaction, absenteeism, and voluntary turnover. Followed by Chonko et al. (2002) that found that "there is a strong positive association between time spent with customers and probability of making quota, indicating a conflict between building relationships with customers, and expected use of IS that might prevent face-to-face interaction with them."

Technostress can be measured by several dimension which is techno-invasion, technooverload, techno-complexity, techno-insecurity, and techno-uncertainty (Ibrahim et al., 2019; Marchiori et al., 2018; Tarafdar et al., 2007), work overload, role ambiguity, invasion of 
privacy, work-home conflict, and job insecurity (Ayyagari et al., 2011), attitude toward technology, workload, work complexity, digital literacy, user involvement, personorganization misfit, person-people misfit, and person-technology enhanced learning (TEL) misfit (Stich et al., 2017; Wang et al., 2020; Zhang et al., 2016). This study used the fivedimensional technostress proposed by Tarafdar et al. (2007). Alam (2016) and Califf \& Brooks (2020) identified techno-complexity as the degree where employees are required to spend their valuable resources (time, money, etc.) to get better understandings and acquires new skills of a particular technology as a result of its complexity. While Sareen (2019) and Tarafdar et al. (2019) defined techno-invasion as a situation in which the users feel the need to be constantly connected with technology even though during non-work time. Gaudioso et al. (2017); and Saka et al. (2020) described techno-overload as a situation in which the users feel that they are forced and requested to work more and faster as a result of technology adoption. Techno-insecurity, on the other hand, is the stress caused by the perceptions that the use of particular technology and its nature of constantly upgrading can threaten them in losing jobs (Güğerçin, 2020; Zainun et al., 2020). They are afraid that "others may know more about new technologies than they do" (Stich et al., 2017). Finally, techno-uncertainty can be described as the unsettled feeling caused by constant changes, upgrades, and the usages of new integration technology that creates ambiguous work requirements and expectations (Güğerçin, 2020; Li \& Wang, 2020).

\section{Technology Usability and Technostress}

Nowadays, the role of employee's perceptions on technology usages becoming critical as it can determine their performance directly especially during the COVID-19 pandemic. Attitudes, experiences, and feel that they have had on information systems, therefore, constitute their technology characteristics perceptions and the level of technology adoption. Ayyagari et al. (2011) defined technology characteristics as an employee's overall assessment toward particular attributes or features of technology. One of the dimensions commonly used by scholars in measuring technology characteristics is usability. Usability is representing the scale of "how well users can use the functionality provided by a particular system or technology" (Nisafani et al., 2020). Ayyagari et al. (2011) identified three dimensions of usability that consist of usefulness, complexity, and reliability. Also, Pal \& Vanijja (2020) divided the usability factors into perceived usefulness and ease to use. While perceived usefulness can be described as the degree to which employees' think that using particular technology would improve their performance (Balog, 2010; Bandiyono \& Muttaqin, 2020; 
DeLone \& McLean, 2003; Jiang et al., 2012), Ying et al. (2021) defined easily of use and reliability as the extent to which attributes and features of a specific technology is enjoyable, free of effort, and dependable. Verkijika (2019) added that although most previous studies confirmed the significant contribution of usability in the level of technology adoption, the association between usability and technology adoption is quite questionable as several recent studies from Chen et al. (2018) and Moorthy et al. (2019) found different results of usability contribution on technology adoption which is either not strong enough or non-significant.

Previous studies from Agogo \& Hess (2015), Ayyagari et al. (2011), Sellberg \& Susi (2014), and Tarafdar et al. (2019) confirmed that usability issues of technology influence the perception of technostress. The more difficult technology usages perceived by employees, the higher the level of stress that is felt by them. In terms of usability dimensional, Foster (2010) explained that "the relationship between complexity and usefulness can be captured by a Ushaped curve." Although his study was conducted in the psychological field, it is common to understand that the more complex technology provided by the company often refers to the lack of usefulness. For example, the software may offer a feature set that useful for employees in order to enhance their productivity (Nisafani et al., 2020). However, at the same time, it also contains hidden and complex functionalities that need to be memories and or operates in detail. Oppositely, Hole (2016) argues that in the ICT (Information \& Computer Technology) field, the complexity of ICT is due primarily to the huge interactions and communications between stakeholders for both operational, managerial, and executive-level and combination of several computer systems within the organization. Therefore, it can offer depth and/or usefulness functionalities to its users.

Furthermore, Kim et al. (2015) and Oh et al. (2019) stated that perceived usefulness has positive influences on users continues use behavior. Considering that the need for connectedness as a description of techno-invasion, it is expected that the more positive evaluation toward the specific technology, the more users are to foresee technology connectedness. Perceived usefulness also proved as negative predictors of techno-overload, Ayyagari et al. (2011) stated that the abilities of employees to do work faster and effectively are enhanced whenever they find the technologies that are designed by the company are useful, thereby it will reduce their work overload perceptions. Finally, since technology's usefulness could lead to the trust of a particular technology. Therefore, the more useful and sophisticated technology that was designed by the company will result in negative technoinsecurity (Tarafdar et al., 2007, 2019) especially "since users who feel insecure typically have little trust in the new technology" (Nugroho \& Fajar, 2017). 
$\mathrm{H}_{1 \mathrm{a}}$ : Technology usability will be associated with techno-complexity.

$\mathrm{H}_{1 b}$ : Technology usability will be associated with techno-invasion.

$\mathrm{H}_{1 \mathrm{c}}$ : Technology usability will be associated with techno-overload.

$\mathrm{H}_{1 \mathrm{~d}}$ : Technology usability will be associated with techno-insecurity.

\section{Technology Presenteeism and Technostress}

Kinman (2019) defined presenteeism as situations in which people continue to work despite difficult conditions (illness). Several studies found that due to the nature of presenteeism that can be categorized as "invisible behavior", the incidence and cost of presenteeism is considerably higher than absenteeism. Knani (2013) added that the costs of presenteeism are underestimated as they are difficult to assess but at the same time impacted in many aspects within the organization such as productivity, service performance, and others. On the other hand, in the case of technology, presenteeism can be described as the degree of hyper-connectivity in which particular technology enables users to be accessible in any situation (Fredette et al., 2012; Issa \& Bahli, 2018). Rainbow \& Steege (2017) added that "presenteeism is a complex behavior that can stem from a variety of antecedents, and lead to cost, performance, and productivity loss for companies."

Furthermore, due to their hyper-connectedness with technology designed by companies, employees have to handle the heavy workload that needs to be accomplished in a short time. This situation therefore often ended on their frustration and exhaustion toward technology. Ayyagari et al. (2011) added that technology presences will cause fragmentations of job tasks due to the increasing amount of communication between an individual that often leads to irresolution tasks. "They perceived a higher job demand because of the increased technology complexity" (Knani, 2013). With the COVID-19 pandemic that is not over yet, the high level of employee reliance on technology obligates them to be constantly available even though they are not in good conditions (sickness) or in time with their families. A study by Xiao \& Mou (2019), found that presenteeism has a positive influence on privacy invasion and invasion of life.

Presenteeism could also manifest in the perception of work overload, as hyperconnectivity is often implied on work faster and longer (Ayyagari et al., 2011). During working from home, the duration of work is not controllable resulted in increasing task exposure with the expectations of faster turnaround times (Valk \& Hannon, 2017). Cooper et al. (2001) stated that hyper-connectivity is perceived as stressors and work overload that is experienced by an individual due to the connectedness with technology. Presenteeism 
Technostress among marketing employee during the COVID-19 pandemic: Exploring the role of technology usability and presenteeism by Khuzaini, Zakky Zamrudi

however may worsen during the implementation of new technologies which is often followed by an increased perceived workload and reluctance to adopt (Knani, 2013). Finally, the presence of technology also has brought a super anxious situation amongst employees. Knani (2013) explained that employees who have been with the company for several years feel more frustration due to the mistreatment, the lack of support and recognition from their companies. They sense that the more they are connected with technology, the more they are realized that their job is in jeopardy (Díaz et al., 2018).

$\mathrm{H}_{2 \mathrm{a}}$ : Technology presenteeism will be associated with techno-complexity.

$\mathrm{H}_{2 \mathrm{~b}}$ : Technology presenteeism will be associated with techno-invasion.

$\mathrm{H}_{2 \mathrm{c}}$ : Technology presenteeism will be associated with techno-overload.

$\mathrm{H}_{2 \mathrm{~d}}$ : Technology presenteeism will be associated with techno-insecurity.

\section{Methods}

This study can be categorized as quantitative and exploratory research as employees' evaluation of specific instruments was represented by numerical data and the objective of this study that wants to investigate and describe the problem that has not been determined. Purposive sampling was chosen as a sampling technique of the study. A survey questionnaire with a five-point of Likert scale was distributed to marketing employees that classified as Indonesia Marketing Association (IMA) active members and have been experienced "working from home" during pandemics situations. Marketing employee was chosen as the object of this study because of the huge impact of COVID-19 to this particular job as the widespread of lockdown and social distancing protocols (He \& Harris, 2020). IMA is also set as a source of marketing employee list as this association is the one of credible marketing associations that have a huge number of Indonesian marketing professionals. The sample size of this study is calculated by using prior study guidance from Machin et al. (2009). A total of 300 employees sent their evaluation about technology usability, presenteeism, and technostress. However, after preliminary analysis of replies, 38 questionnaires that were filled out incompletely need to be withdrawn. Thus, there are 262 (which represents $87.33 \%$ response rates) valid questionnaires that were classified to be processed into the goodness of fit model testing, reliability and (convergent and discriminant) validity testing, and Covariance Based Structural Equation Modeling (CB-SEM) analysis.

CB-SEM has seen a drastic increase in attention and utilization over the last decade (Astrachan et al., 2014). Hair et al. (2014) added that CB-SEM aims to "reproduces the covariance matrix (i.e., minimizing the difference between the observed and estimated 
covariance matrix) without focusing on explained variance”. CB-SEM should be passed and followed all the criterion of the goodness of fit models such as absolute fit (which consist of chi-square, Root Mean Square Error Approximation-RMSEA, Goodness Fit Index-GFI) and incremental fit evaluation (which consist of Adjusted Good of Fit-AGFI, Comparative Fit Index-CFI, Tucker Lewis Index-TLI, the degrees of freedom). To be classified as a good fit model, Hair et al. (2014) declared that the (cut-off) score of chi-square should be as small as possible with RMSEA score that is lower than 0.080, GFI and AGFI score that is higher than 0.900 , the degree of freedom (CMIN/df) value that is lower than $\leq 2.00$, TLI and CFI score that is higher than 0.950 .

In this study, the construct was adjusted from several previous studies. While the technology usability and presenteeism were adapted from Ayyagari et al. (2011), Tarafdar et al. (2014) items, technostress creator factors which consist of techno-complexity, technoinvasion, techno-overload, techno-insecurity, and techno-uncertainty was measured by Ma \& Turel (2019) and Marchiori et al. (2018) instruments. However, we opted to remove technouncertainty from the model due to the reason that all questionnaire items from this stressor are invalid during the pre-test with 200 respondents. Murray (2006) stated that avoiding invalid instruments is the right thing to do in the nature of research as invalid instruments produce a biased and troublesome instrumental variable estimator which may be much more biased if the omitted variables are correlated with the existing explanators. Figure 1 and Table 1 show the research framework and the detailed information of the research instrument.

Figure 1. Research Framework

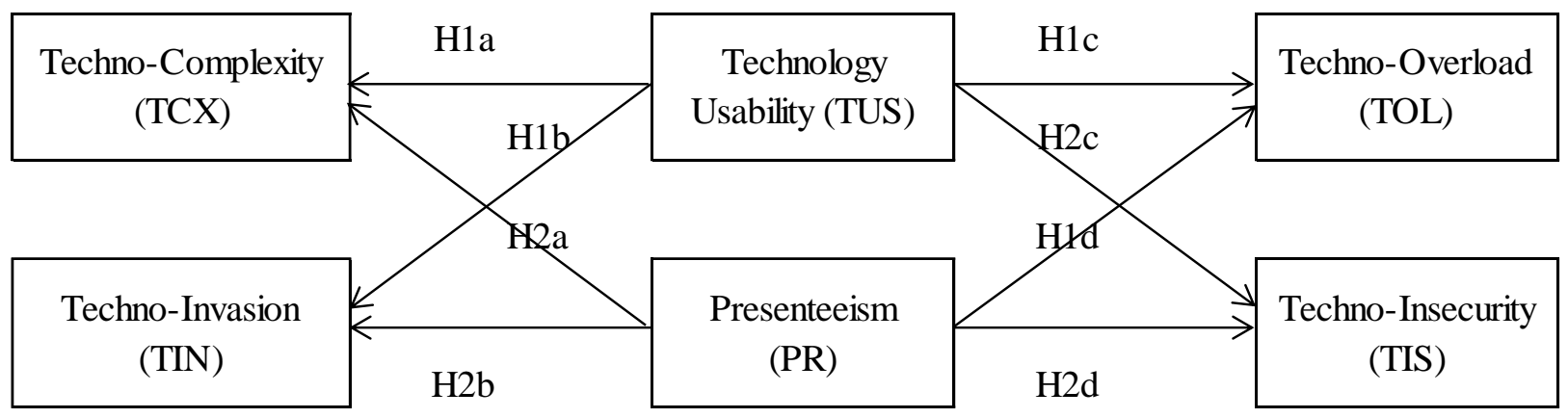


Technostress among marketing employee during the COVID-19 pandemic: Exploring the role of technology usability and presenteeism by Khuzaini, Zakky Zamrudi

Table 1. Research Instruments

\begin{tabular}{lll}
\hline Variable & Code & Item \\
\hline Technology & TUS1 & The use of technology makes me finish my tasks more quickly \\
Usability (TUS) & TUS2 & The use of technology increase the quality of my work \\
& TUS3 & The use of technology makes my job easier to finish \\
& TUS4 & The use of technology enhances my effectiveness on the job. \\
Presenteeism & PRE1 & The use of technology enables me to be in touch with others. \\
(PR) & PRE2 & The use of ICTs enables me to work from a distance \\
Techno- & TCX1 & I do not know enough about technology to address my work \\
(TCX) & satisfactorily \\
& TCX2 & I need a long time to understand and use new technologies \\
& TCX4 & I don't have enough time to learn more and catch up with technology \\
& technology than I do
\end{tabular}

Techno-Invasion TIN1 I have less time with my family due to the technology used at work (TIN)

TIN2 I am in contact with work even during vacation because of the technology used at work

TIN3 I have to sacrifice my vacation time and weekends to keep myself up-to-date with new technologies

TIN4 I feel that the technology used at work invading my personal life

Techno-Overload TOL1 I am forced to work faster because of the technology used at work (TOL)

TOL2 I am forced to work more because of the technology used at work

TOL3 I am forced to work with very tight schedules because of the technology used at work

TOL4 I was forced to change habit my working time to adapt to new technologies

TOL5 I have a larger workload due to increased technological complexity

Techno-

Insecurity

(TIS)

TIS1 I feel a constant threat to my job security due to new technologies.

TIS2 I am threatened by coworkers with newer technology skills.

TIS3 I don't share my knowledge with my coworkers for fear of being replaced.

TIS4 I feel there is a lack of knowledge sharing among coworkers for fear of being replaced. 
Table 2. The Goodness-of-Fit (GoF) Model

\begin{tabular}{cccc}
\hline Criteria & Output & Cut-Off Criteria & Decision \\
\hline Chi-Square & 2.314 & Smaller & Accepted \\
RMSEA & 0.000 & $\leq 0.08$ & Accepted \\
GFI & 0.955 & $\geq 0.90$ & Accepted \\
AGFI & 0.915 & $\geq 0.90$ & Accepted \\
CMIN/DF & 0.632 & $\leq 2.00$ & Accepted \\
TLI & 0.908 & $\geq 0.95$ & Accepted \\
CFI & 0.978 & $\geq 0.95$ & Accepted \\
\hline
\end{tabular}

Table 2 indicates that indices can be considered acceptable as all the criteria index of GoF were met in this study. The results of GoF test show that the value of Chi-Square is 2.314 with RMSEA of $0.000(<0.080)$, GFI and AGFI value of $0.915(>0.900)$, the degree of freedom $(\mathrm{CMIN} / \mathrm{df})$ value of $0.632(<2.000)$, TLI and CFI score of 0.908 and 0.978 (> 0.950). Thus, the measurement model of construct and reliability, convergent and discriminant validity was evaluated by using Hair et al. (2014) guidance. Table 4 shows that the Cronbach's alpha of the six constructs is above the accepted value of 0.700 (ranged from 0.801 to 0.853 ) which means that technology usability, presenteeism, techno-complexity, techno-invasion, techno-overload, and techno-insecurity had sufficient reliability. Furthermore, this study had adequate convergent validity as the constructs of composite reliability and the average variance extracted (AVE) score exceeds the accepted value of 0.700 and 0.500 . While, the composite reliability of all constructs was between 0.811 to 0.886 , each construct's AVE ranging from 0.503 to 0.673 . Finally, discriminant validity was measure by using the square roots of the AVE for each construct that must be higher than on other constructs. Table 3 shows the discriminant validity was met in this study.

Table 3. Discriminant Validity

\begin{tabular}{lllllll}
\hline Constructs & TUS & PRE & TCX & TIN & TOL & TIS \\
\hline Technology Usability (TUS) & 0.892 & & & & & \\
Presenteeism (PRE) & 0.221 & 0.830 & & & & \\
Techno-Complexity (TCX) & 0.067 & 0.268 & 0.738 & & & \\
Techno-Invasion (TIN) & 0.384 & 0.220 & 0.188 & 0.738 & & \\
Techno-Overload (TOL) & 0.480 & 0.442 & 0.118 & 0.393 & 0.808 & \\
Techno-Insecurity (TIS) & 0.519 & 0.369 & 0.077 & 0.336 & 0.618 & 0.812 \\
\hline
\end{tabular}


Table 4. Reliability, Convergent Validity, and Average Variance Extracted (AVE)

\begin{tabular}{|c|c|c|c|c|}
\hline $\begin{array}{l}\text { Construct/ } \\
\text { Items }\end{array}$ & $\begin{array}{l}\text { Loading } \\
\text { Factor }\end{array}$ & $\begin{array}{c}\text { Cronbach's } \\
\text { Alpha }\end{array}$ & AVE & $\begin{array}{l}\text { Composite } \\
\text { Reliability }\end{array}$ \\
\hline TUS & & 0.817 & 0.532 & 0.886 \\
\hline TUS1 & 0.786 & & & \\
\hline TUS2 & 0.833 & & & \\
\hline TUS3 & 0.781 & & & \\
\hline TUS4 & 0.792 & & & \\
\hline PRE & & 0.801 & 0.643 & 0.805 \\
\hline PRE1 & 0.793 & & & \\
\hline PRE2 & 0.838 & & & \\
\hline TCX & & 0.813 & 0.673 & 0.815 \\
\hline TCX1 & 0.795 & & & \\
\hline TCX2 & 0.780 & & & \\
\hline TCX3 & 0.819 & & & \\
\hline $\mathrm{TCX} 4$ & 0.795 & & & \\
\hline TCX5 & 0.886 & & & \\
\hline TIN & & 0.809 & 0.503 & 0.811 \\
\hline TIN1 & 0.714 & & & \\
\hline TIN2 & 0.751 & & & \\
\hline TIN3 & 0.754 & & & \\
\hline TIN4 & 0.814 & & & \\
\hline TOL & & 0.856 & 0.544 & 0.822 \\
\hline TOL1 & 0.712 & & & \\
\hline TOL2 & 0.754 & & & \\
\hline TOL3 & 0.735 & & & \\
\hline TOL4 & 0.835 & & & \\
\hline TOL5 & 0.811 & & & \\
\hline TIS & & 0.853 & 0.593 & 0.817 \\
\hline TIS1 & 0.745 & & & \\
\hline TIS2 & 0.803 & & & \\
\hline TIS3 & 0.819 & & & \\
\hline TIS4 & 0.712 & & & \\
\hline
\end{tabular}




\section{Result and Discussion}

Table 5. Demographic Profiles

\begin{tabular}{|c|c|c|c|}
\hline \multicolumn{2}{|c|}{ Demographic Variables } & \multirow{2}{*}{$\begin{array}{c}\text { Frequency } \\
157\end{array}$} & \multirow{2}{*}{$\frac{\text { Percentages }(\%)}{55}$} \\
\hline Gender & Male & & \\
\hline & Female & 105 & 45 \\
\hline \multirow[t]{7}{*}{ Age } & $21-25$ & 42 & 16 \\
\hline & $26-30$ & 61 & 23 \\
\hline & $31-35$ & 48 & 19 \\
\hline & $36-40$ & 35 & 14 \\
\hline & $41-45$ & 29 & 11 \\
\hline & $46-50$ & 25 & 10 \\
\hline & $>50$ & 22 & 7 \\
\hline \multirow[t]{4}{*}{ Education } & Senior High School & 76 & 29 \\
\hline & Diploma & 73 & 28 \\
\hline & Bachelor & 82 & 31 \\
\hline & Master & 31 & 12 \\
\hline \multirow{4}{*}{$\begin{array}{l}\text { Technology } \\
\text { Usage } \\
\text { Duration }\end{array}$} & $1-3$ Hours & 78 & 30 \\
\hline & $4-6$ Hours & 113 & 43 \\
\hline & $7-9$ Hours & 60 & 23 \\
\hline & $>9$ Hours & 11 & 4 \\
\hline \multirow{5}{*}{$\begin{array}{l}\text { Work } \\
\text { Experience }\end{array}$} & $1-4$ Years & 97 & 37 \\
\hline & $4-7$ Years & 82 & 31 \\
\hline & $7-10$ Years & 42 & 16 \\
\hline & $11-14$ Years & 26 & 10 \\
\hline & $>14$ Years & 15 & 6 \\
\hline
\end{tabular}

Table 5 of demographic profiles shows that most of the 262 respondents in this study are male $(55 \%)$ and $45 \%$ are female. In addition, there was a predominance of respondents with ages ranging between 26-30 years (23\%) and who have a Bachelor's degree (31\%). The majority of them also classified that they are new in their recent companies (1-4 years of service) and have accessed technology for about 4-6 hours each day for work purposes (37\%). To summarize, most of the respondents in this study are in productive age with the level of technology usages in work that is still considered as normal and reasonable when compared to their daily working hours. 
Technostress among marketing employee during the COVID-19 pandemic: Exploring the role of technology usability and presenteeism by Khuzaini, Zakky Zamrudi

Table 6. Hypotheses Testing

\begin{tabular}{lccccc}
\hline Hypotheses & Estimates & SE & CR & P & Decision \\
\hline $\mathrm{H}_{1 \mathrm{a}}$ TUS -> TCX & 0.410 & 0.085 & 4.846 & $* * *$ & Supported \\
$\mathrm{H}_{1 \mathrm{~b}}$ TUS -> TIN & 0.132 & 0.070 & 1.888 & 0.079 & Not Supported \\
$\mathrm{H}_{1 \mathrm{c}}$ TUS -> TOL & 0.132 & 0.069 & 1.910 & 0.076 & Not Supported \\
$\mathrm{H}_{1 \mathrm{~d}}$ TUS -> TIS & 0.182 & 0.068 & 2.594 & 0.013 & Supported \\
$\mathrm{H}_{2 \mathrm{a}}$ PRE -> TCX & -0.300 & 0.160 & -1.876 & 0.081 & Not Supported \\
$\mathrm{H}_{2 \mathrm{~b}}$ PRE -> TIN & -0.155 & 0.132 & -1.178 & 0.273 & Not Supported \\
$\mathrm{H}_{2 \mathrm{c}}$ PRE -> TOL & -0.355 & 0.131 & -2.720 & 0.011 & Supported \\
$\mathrm{H}_{2 \mathrm{~d}}$ PRE -> TIS & -0.333 & 0.128 & -2.598 & 0.016 & Supported \\
\hline
\end{tabular}

Table 6 shows the effect of technology usability (TUS) and presenteeism (PRE) on the techno-stress dimension such as techno-complexity (TCX), techno-invasion (TIN), technooverload (TOL), techno-insecurity (TIS). As shown in previous studies, the cut-off value for hypothesis testing is in the range between the Critical Ratio t-value $>1.96$ or $<-1.96$ at the 0.05 significant level (Arbuckle, 2010; Hair et al., 2019). The result of hypotheses testing in Table 6 shows that the technology usability shows a significant effect on techno-complexity of $0.410(\mathrm{CR}=4.846)$ and techno insecurity of $0.182(\mathrm{CR}=2.594)$, while the effect on techno-invasion shows $0.132(\mathrm{CR}=1.888)$ and techno-overload of $0.042(\mathrm{CR}=1.910)$ which indicates insignificant effect. However, the greatest influence is shown by the influence of technology usability on the complexity of the technology. Thus, it can be concluded that the use of technology by marketing employees can increase their level of anxiety and worries about being irrelevant and jobless due to the complexity of technology that was implemented by the company. Especially as Geiger \& Turley (2006) and Rangarajan et al. (2005) argued that marketing people would rather spend most of their time interacting with consumers than in front of a computer screen.

The development of technology is used to simplify work and shorten the time of tasks completion of both the operational and managerial levels (the impact of these technological developments can be seen in the availability of application that supports with nature "working from home" during the COVID-19 pandemic). The findings of this study indicate a positive and significant relationship between technology usability and technology complexity. This study supports the finding of Hole (2016) that stated that useful systems and information technology require more complicated relationship and cross-departmental collaboration. The lack of non-virtual meetings, face-to-face meetings, to discuss a job can bring it into a more 
complex situation and time-consuming (Ayyagari et al., 2011). During a pandemic situation, it is difficult to conduct face-to-face meetings among the employees. Therefore, the accessibility of a proper technology or application can make works becoming easier. A work that previously was only done in the office, it is currently can be done at home during the quarantine period. Hole (2016) and Srivastava et al. (2015) added that the resulting cumulative work complexity can be reduced when technology is considered capable to support job achievement.

In the second dimension of technological characteristics, the presence of technology (presenteeism) shows a negative effect on all techno-stress dimensions. The effect of presenteeism on techno-complexity shows an effect of $-0.300(\mathrm{CR}=-1.876)$, and the effect of presenteeism on the invasion of technology shows an effect of -0.155 (CR $=-1.178)$ which shows an insignificant effect. The effect of presenteeism on techno-overload and technoinsecurity shows the probability value of $-0.355(\mathrm{CR}=-2.720)$ and $-0.333, \mathrm{CR}=-2.598)$ which indicates a significant effect. Therefore, it can be concluded that presenteeism can significantly reduce techno-overload and techno-insecurity.

The result of this study contradicts the conclusion of Galluch et al. (2015), which stated the hyper-connectivity will cause massive job demands that often ended in an overload of work. The nature of respondent in this study that only uses technology for about 4-6 hours each day for work purposes is still considered as normal and reasonable when compared to their daily working hours (8-9 hours). During the pandemic situation, the implementation of lockdown and social distancing mandates by governments caused the massive adjustment of marketing programs. Marketing automation becoming companies' focus in recent days. Thus, it will ease the burden of the target performance of each marketing employee. Ayyagari et al. (2011) added that the presence of technology could increase work effectiveness and efficiencies that resulted in work-life balance (Chandra et al., 2019). It is hoped that the use of technology does not only create a balance between the numbers of jobs but also work rhythm (Agogo \& Hess, 2015).

Interestingly, this study found the negative effect of technology presenteeism on technoinsecurity. Many marketing employees still believed that physical meeting remains important and cannot be replaced with technology (Gschwandtner, 2011; Tarafdar et al., 2014). The challenges that have arisen due to the pandemic (such as lockdowns, social distancing, and application of various health protocols), have affected the ways companies run their marketing campaign from conventional marketing to technology-based marketing. However, the reliance of many marketing programs on technology does not make marketing employees 
Technostress among marketing employee during the COVID-19 pandemic: Exploring the role of technology usability and presenteeism by Khuzaini, Zakky Zamrudi

feel threatened by technology. They consider the current radical changes only temporary and will last during the pandemic. The results of this study indicate that they will only feel insecure when this technology can provide significant benefits to the company. Interestingly, marketing employees do not see their connectivity with technology impact on massive workloads (even it has reduced their working hours from 8 hours to 4-6 hours per day during the pandemic). It indicates that the presence of technology has provided tangible benefits to companies. Thus, if this condition is not anticipated properly, the technology-based marketing will cause major disruption to many marketeers after the pandemic.

The presence of technology is expected to provide an effective alternative for workers during a pandemic and to enable them to work from home. Table 6 shows the insignificant effect of technology's usability on techno-invasion and techno-overload and technology's presenteeism on techno-complexity and techno-invasion. This result indicate that technoinvasion and techno-overload are generally not shared by all members. There may be internal communication that reduces techno-overload such as communication support and an increase in the technological capacity of the company (Pflügner \& Maier, 2019). Companies can provide frequent and effective training programs to improve the technical skills of employees to reduce employee anxiety (Fuglseth \& Sørebø, 2014). A working environment that supports both physical and non-physical environments is considered important to reduce technological insecurity because adequate support from colleagues and supervisors is proven to reduce technological insecurity when employees feel unsafe (Goetz \& Boehm, 2020). Also, Califf \& Brooks (2020) stated that the interaction duration with technology will cause different levels of understanding and literacy between an employee that will affect a different level of stress. The higher technology connectivity, the higher the level of stress will be. From the demographic profile, it is known that the use of technology of 4-6 hours is considered sufficient when compared to office regular working hours of 8-9 hours a day. Thus, the study indicates a non-significant effect due to lack of time learning on the benefit of using technology in the marketing department. Another factor creates such condition is due to demands in certain product particularly on electronics and mobile devices increases as people is working and learning from home, resulting in lower workloads of marketing employee.

\section{Conclusion and Suggestion}

This study aims to investigate the associations of technology usability and presenteeism on technostress dimensions such as techno-complexity, techno-overload, techno-invasion, and techno-insecurity. The result of this study concluded that technology usability has 
positive influences on techno-complexity and techno-insecurity. While at the same time, the negative influences of technology presenteeism (hyper-connectivity) on techno-overload and techno-insecurity were also proved in this study. The majority of the respondent in this study that uses technology in the normal range (4-6 hours) and the focus of their companies to implement marketing automation during the COVID-19 pandemic situations were considered as the main reason for the negativity effect between technology presenteeism (hyperconnectivity) on techno-overload and techno-insecurity. The multi-challenges that have arisen due to the pandemic (such as lockdowns, social distancing, and application of various health protocols), have affected the changes in the company's marketing strategy from conventional marketing to technology-based marketing. However, the reliance of many marketing programs on technology does not make marketing employees feel threatened by technology. They consider the current radical changes only temporary and will only last during the pandemic. The results of this study also indicate that they will only feel insecure when this technology can provide significant benefits to the company. Interestingly, marketing employees do not see their connectivity with technology impact on excess workloads (even it has reduced their working hours from 8 hours to 4-6 hours per day during the pandemic). It indicates that the presence of technology has provided tangible benefits to companies. Thus, if this condition is not anticipated properly, the technology-based marketing will cause major disruption to many marketeers after the pandemic. Future studies are encouraged to include individual technology capabilities as one of the technology characteristic measurements since the level of technical characteristics can differ between individuals. To get a better understanding of techno-stress, demographic profiles (such as education level and duration of technology use), organizational culture (knowledge sharing), and work environment should also be considered as other stress predictors.

\section{References}

Agogo, D., \& Hess, T. J. (2015). Technostress and Technology Induced State Anxiety: Scale Development and Implications. Thirty Sixth International Conference on Information Systems (ICIS), 1-11.

Ahearne, M., \& Rapp, A. (2010). The role of technology at the interface between salespeople and consumers. Journal of Personal Selling and Sales Management, 30(2), 111-120. https://doi.org/10.2753/PSS0885-3134300202

Alam, M. A. (2016). Techno-stress and productivity: Survey evidence from the aviation industry. Journal of Air Transport Management, 50, 62-70. 
Technostress among marketing employee during the COVID-19 pandemic: Exploring the role of technology usability and presenteeism by Khuzaini, Zakky Zamrudi

https://doi.org/10.1016/j.jairtraman.2015.10.003

Arbuckle, J. L. (2010). IBM SPSS Amos 19 User's Guide. Amos Development Corporation.

Astrachan, C. B., Patel, V. K., \& Wanzenried, G. (2014). A comparative study of CB-SEM and PLS-SEM for theory development in family firm research. Journal of Family Business Strategy, 5(1), 116-128. https://doi.org/10.1016/j.jfbs.2013.12.002

Atanasoff, L., \& Venable, M. A. (2017). Technostress: Implications for Adults in the Workforce. Career Development Quarterly, 65(4), 326-338. https://doi.org/10.1002/cdq.12111

Ayyagari, R., Grover, V., \& Purvis, R. (2011). Technostress: Technological antecedents and implications. MIS Quarterly: Management Information Systems, 35(4), 831-858. https://doi.org/10.2307/41409963

Balog, A. (2010). The Role of Perceived Enjoyment in the Students' Acceptance of an Augmented Reality Teaching Platform: a Structural Equation Modelling Approach Noninvasive monitoring and health assessment of the elderly in a smart environment (ROSmartAgeing) View project Romanian literary heritage conservation and intelligent digital solutions for knowledge extraction and systematization-INTELLIT View project. Studies in Informatics and Control, 19(3). https://doi.org/10.24846/v19i3y201011

Bandiyono, A., \& Muttaqin, A. H. H. (2020). Investigating the success of an E-Auction system initiatives among public servants: Validation of an integrated IS success model. JEMA: Jurnal Ilmiah Bidang Akuntansi Dan Manajemen, 17(2), 188. https://doi.org/10.31106/jema.v17i2.9044

Boonjing, V., \& Chanvarasuth, P. (2017). Risk of overusing mobile phones: Technostress $\begin{array}{llll}\text { effect. } & \text { Procedia }\end{array}$ https://doi.org/10.1016/j.procs.2017.06.053

Brem, A., Viardot, E., \& Nylund, P. A. (2021). Implications of the coronavirus (COVID-19) outbreak for innovation: Which technologies will improve our lives? Technological $\begin{array}{lllll}\text { Forecasting } & \text { Social }\end{array}$ https://doi.org/10.1016/j.techfore.2020.120451

Brod, C. (1982). Managing Technostress: Optimizing the Use of Computer Technology. Personnel Journal, 61(10), 753-757.

Califf, C. B., \& Brooks, S. (2020). An empirical study of techno-stressors, literacy facilitation, burnout, and turnover intention as experienced by K-12 teachers. Computers and Education, 157, 103971. https://doi.org/10.1016/j.compedu.2020.103971

Chandra, S., Shirish, A., \& Srivastava, S. C. (2019). Does technostress inhibit employee 
innovation? Examining the linear and curvilinear influence of technostress creators. Communications of the Association for Information Systems, 44(1), 299-331. https://doi.org/10.17705/1CAIS.04419

Chen, S. C., Yen, D. C., \& Peng, S. C. (2018). Assessing the impact of determinants in emagazines acceptance: an empirical study. Computer Standards \& Interfaces, 57, 49-58. https://doi.org/10.1016/j.csi.2017.11.004

Chonko, L. B., Jones, E., Roberts, J. A., \& Dubinsky, A. J. (2002). The role of environmental turbulence, readiness for change, and salesperson learning in the success of sales force change. Journal of Personal Selling \& Sales Management, 22(4), 227-245. https://doi.org/10.1080/08853134.2002.10754311.

Christ-Brendemühl, S., \& Schaarschmidt, M. (2020). The impact of service employees' technostress on customer satisfaction and delight: A dyadic analysis. Journal of Business Research, 117, 378-388. https://doi.org/10.1016/j.jbusres.2020.06.021

Cooper, C., Dewe, P. and O'Driscoll, M. (2001) Organizational stress: a review and critique of theory, research, and applications, Thousand Oaks, CA: Sage, pp.270.

Cooper, C. D., \& Kurland, N. B. (2002). Telecommuting, professional isolation, and employee development in public and private organizations. Journal of Organizational Behavior, 23(4), 511-532. https://doi.org/10.1002/job.145

DeLone, W. H., \& McLean, E. R. (2003). The DeLone and McLean model of information systems success: A ten-year update. Journal of Management Information Systems, 19(4), 9-30. https://doi.org/10.1080/07421222.2003.11045748

Dhomane, P., \& Mathew, R. (2021). Counter-measures to spoofing and jamming of drone signals. SSRN Electronic Journal. https://doi.org/10.2139/ssrn.3774955

Díaz, E., Martín-Consuegra, D., \& Esteban, Á. (2018). The effect of new technologies on psychological consequences and risk perceptions of sales agents. Journal of Risk Research, 21(11), 1409-1429. https://doi.org/10.1080/13669877.2017.1313763

Durucu, M., \& Bayraktar, C. A. (2020). The Effect of Working from Home on Work and Private Life: Automotive Sector Application. In Industrial Engineering in the Digital Disruption Era (pp. 148-155). https://doi.org/10.1007/978-3-030-42416-9_14

Foster, E. M. (2010). The U-Shaped relationship between complexity and usefulness: A commentary. In Developmental Psychology (Vol. 46, Issue 6, pp. 1760-1766). https://doi.org/10.1037/a0020180

Fredette, J., Marom, R., Steiner, K., \& Witters, L. (2012). The promise and peril of hyperconnectivity for organizations and societies. The Global Information Technology 
Technostress among marketing employee during the COVID-19 pandemic: Exploring the role of technology usability and presenteeism by Khuzaini, Zakky Zamrudi Report, 113-119.

Fuglseth, A. M., \& Sørebø, Ø. (2014). The effects of technostress within the context of employee use of ICT. Computers in Human Behavior, 40, 161-170. https://doi.org/10.1016/j.chb.2014.07.040

Galluch, P. S., Grover, V., \& Thatcher, J. B. (2015). Interrupting the workplace: Examining stressors in an information technology context. Journal of the Association for Information Systems, 16(1), 1-47. https://doi.org/10.17705/1jais.00387

Gaudioso, F., Turel, O., \& Galimberti, C. (2017). The mediating roles of strain facets and coping strategies in translating techno-stressors into adverse job outcomes. Computers in Human Behavior, 69, 189-196. https://doi.org/10.1016/j.chb.2016.12.041

Geiger, S., \& Turley, D. (2006). The Perceived Impact of Information Technology on Salespeople's Relational Competencies. Journal of Marketing Management, 22(7-8), 827-851. https://doi.org/10.1362/026725706778612158

Goetz, T. M., \& Boehm, S. A. (2020). Am I outdated? The role of strengths use support and friendship opportunities for coping with technological insecurity. Computers in Human Behavior, 107, 106265. https://doi.org/10.1016/j.chb.2020.106265

Gschwandtner, L. (2011). Fifteen Million Salespeople to Be Displaced by 2020, Predicts Sales 2.0 Conference Host.

Güğerçin, U. (2020). Does techno-stress justify cyberslacking? An empirical study based on the neutralisation theory. Behaviour and Information Technology, 39(7), 824-836. https://doi.org/10.1080/0144929X.2019.1617350

Hair, J. F., Gabriel, M. L. D. da S., \& Patel, V. K. (2014). AMOS Covariance-Based Structural Equation Modeling (CB-SEM): Guidelines on its Application as a Marketing Research Tool. Revista Brasileira de Marketing, 13(02), 44-55. https://doi.org/10.5585/remark.v13i2.2718

Hair, J. F., Risher, J. J., Sarstedt, M., \& Ringle, C. M. (2019). When to use and how to report the results of PLS-SEM. European Business Review, 31(1), 2-24. https://doi.org/10.1108/EBR-11-2018-0203

He, H., \& Harris, L. (2020). The impact of Covid-19 pandemic on corporate social responsibility and marketing philosophy. Journal of Business Research, 116, 176-182. https://doi.org/10.1016/j.jbusres.2020.05.030

Hole, K. J. (2016). Anti-fragile ICT Systems. In Anti-fragile ICT Systems. Springer International Publishing. https://doi.org/10.1007/978-3-319-30070-2

Hung, W. H., Chen, K., \& Lin, C. P. (2015). Does the proactive personality mitigate the 
adverse effect of technostress on productivity in the mobile environment? Telematics and Informatics, 32(1), 143-157. https://doi.org/10.1016/j.tele.2014.06.002

Ibrahim, H., Mohd Shamsudin, F., Mohd Yusoff, Y., \& Mohd Zin, M. L. (2019). Exploring technology characteristics as antecedents of technostress with hrmis in government agencies of Malaysia: A mixed-method research. Test Engineering and Management, $81,1053-1065$.

Issa, H., \& Bahli, B. (2018). Understanding the consequences of technostress: A non-linear perspective. 26th European Conference on Information Systems: Beyond Digitization Facets of Socio-Technical Change, ECIS 2018.

Jiang, K., Lepak, D. P., Han, K., Hong, Y., Kim, A., \& Winkler, A. L. (2012). Clarifying the construct of human resource systems: Relating human resource management to employee performance. Human Resource Management Review, 22(2), 73-85. https://doi.org/10.1016/j.hrmr.2011.11.005

Khan, A., Rehman, H., \& Shafiq-ur-Rehman. (2013). An empirical analysis of correlation between technostress and job satisfaction: A case of KPK, Pakistan. Pakistan Journal of Library and Information Science, 14(14), 9-15. https://www.scopus.com/inward/record.uri?partnerID=HzOxMe3b\&scp=84893952509 \&origin=inward

Kim, C., Hwang, J. S., \& Cho, J. (2015). Relationships among mobile fashion shopping characteristics, perceived usefulness, perceived enjoyment, and purchase intentionMediating effect of ease of use. Journal of the Korean Society of Clothing and Textiles, 39(2), 161-174. https://doi.org/10.1016/j.chb.2019.01.003

Kinman, G. (2019). Sickness presenteeism at work: Prevalence, costs and management. In British Medical Bulletin (Vol. 129, Issue 1, pp. 107-116). Oxford University Press. https://doi.org/10.1093/bmb/ldy043

Knani, M. (2013). Exploratory Study of the Impacts of New Technology Implementation on Burnout and Presenteeism. Article in International Journal of Business and Management, 8(22). https://doi.org/10.5539/ijbm.v8n22p92

Li, L., \& Wang, X. (2020). Technostress inhibitors and creators and their impacts on university teachers' work performance in higher education. Cognition, Technology and Work. https://doi.org/10.1007/s10111-020-00625-0

Liljander, V., Gillberg, F., Gummerus, J., \& van Riel, A. (2006). Technology readiness and the evaluation and adoption of self-service technologies. Journal of Retailing and Consumer Services, 13(3), 177-191. https://doi.org/10.1016/j.jretconser.2005.08.004 
Technostress among marketing employee during the COVID-19 pandemic: Exploring the role of technology usability and presenteeism by Khuzaini, Zakky Zamrudi

Ma, Y., \& Turel, O. (2019). Information technology use for work and technostress: effects of power distance and masculinity culture dimensions. Cognition, Technology and Work, 21(1), 145-157. https://doi.org/10.1007/s10111-018-0503-1

Machin, D., Campbell, M. J., Tan, S. B., \& Tan, S. H. (2009). Sample Size Tables for Clinical Studies: Third Edition. In Sample Size Tables for Clinical Studies: Third Edition. Wiley-Blackwell. https://doi.org/10.1002/9781444300710

Mahboob, A. (2016). Technostress and Its Management Techniques: A Literature Review. Journal of Human Resource Management, 4(3), 28. https://doi.org/10.11648/j.jhrm.20160403.12

Marchiori, D. M., Mainardes, E. W., \& Rodrigues, R. G. (2018). Do Individual Characteristics Influence the Types of Technostress Reported by Workers? International Journal of Human-Computer Interaction, 35(3), 218-230. https://doi.org/10.1080/10447318.2018.1449713

Moorthy, K., Chun T'ing, L., Ming, K. S., Ping, C. C., Ping, L. Y., Joe, L. Q., \& Jie, W. Y. (2019). Behavioral intention to adopt digital library by the undergraduates. International $\begin{array}{llll}\text { Information } \quad \& \quad \text { Library } & \text { Review, }\end{array}$ https://doi.org/10.1080/10572317.2018.1463049

Murray, M. P. (2006). Avoiding invalid instruments and coping with weak instruments. Journal of Economic Perspectives, 20(4), 111-132. https://doi.org/10.1257/jep.20.4.111

Nisafani, A. S., Kiely, G., \& Mahony, C. (2020). Workers' technostress: a review of its causes, strains, inhibitors, and impacts. Journal of Decision Systems. https://doi.org/10.1080/12460125.2020.1796286

Nugroho, M. A., \& Fajar, M. A. (2017). Effects of Technology Readiness Towards Acceptance of Mandatory Web-Based Attendance System. Procedia Computer Science, 124, 319-328. https://doi.org/10.1016/j.procs.2017.12.161

Oh, Y. J., Park, H. S., \& Min, Y. (2019). Understanding location-based service application connectedness: Model development and cross-validation. Computers in human behavior, 94, 82-91. https://doi.org/10.5850/JKSCT.2015.39.2.161

Pal, D., \& Vanijja, V. (2020). Perceived usability evaluation of Microsoft Teams as an online learning platform during COVID-19 using system usability scale and technology acceptance model in India. Children and youth services review, 119, 105535. https://doi.org/10.1016/j.childyouth.2020.105535

Pflügner, K., \& Maier, C. (2019). Mitigating technostress: An empirical study of mindfulness and techno-stressors. In 25th Americas Conference on Information Systems, AMCIS 
2019.

Raghuram, S., Hill, N. S., Gibbs, J. L., \& Maruping, L. M. (2019). Virtual Work: Bridging Research Clusters. Academy of Management Annals, 13(1), 308-341. https://doi.org/10.5465/annals.2017.0020

Rainbow, J. G., \& Steege, L. M. (2017). Presenteeism in nursing: An evolutionary concept analysis. Nursing Outlook, 65(5), 615-623. https://doi.org/10.1016/j.outlook.2017.03.005

Rangarajan, D., Jones, E., \& Chin, W. (2005). Impact of sales force automation on technology-related stress, effort, and technology usage among salespeople. Industrial Marketing Management, $34(4 \quad$ SPEC ISS.), 345-354. https://doi.org/10.1016/j.indmarman.2004.09.015

Rupietta, K., \& Beckmann, M. (2018). Working from Home. Schmalenbach Business Review, 70(1), 25-55. https://doi.org/10.1007/s41464-017-0043-x

Saka, A. O., Alaba, A. O., \& Hassan, O. A. (2020). The Impact of Technostressors on the Job Productivity of Senior Secondary Teachers in Nigeria. Journal of Teaching and Teacher Education, 2(2), 105-113. https://doi.org/http://dx.doi.org/10.12785/jtte/080205

Sareen, P. (2019). Techno Stress Creators-An Exploratory Research on Teaching and Non Teaching Staff Working in Colleges. International Journal of Management and Humanities (IJMH), 3(9), 1-7.

Sellberg, C., \& Susi, T. (2014). Technostress in the office: A distributed cognition perspective on human-technology interaction. Cognition, Technology and Work, 16(2), 187-201. https://doi.org/10.1007/s10111-013-0256-9

Speier, C., \& Venkatesh, V. (2002). The Hidden Minefields in the Adoption of Sales Force Automation Technologies. Journal of Marketing, 66(3), 98-111. https://doi.org/10.1509/jmkg.66.3.98.18510

Srivastava, S. C., Chandra, S., \& Shirish, A. (2015). Technostress creators and job outcomes: Theorising the moderating influence of personality traits. Information Systems Journal, 25(4), 355-401. https://doi.org/10.1111/isj.12067

Stich, J. F., Tarafdar, M., Cooper, C. L., \& Stacey, P. (2017). Workplace stress from actual and desired computer-mediated communication use: a multi-method study. New Technology, Work and Employment, 32(1), 84-100. https://doi.org/10.1111/ntwe.12079

Tarafdar, M., Cooper, C. L., \& Stich, J. F. (2019). The technostress trifecta - techno eustress, techno distress and design: Theoretical directions and an agenda for research. Information Systems Journal, 29(1), 6-42. https://doi.org/10.1111/isj.12169 
Technostress among marketing employee during the COVID-19 pandemic: Exploring the role of technology usability and presenteeism by Khuzaini, Zakky Zamrudi

Tarafdar, M., Pullins, E. B., \& Ragu-Nathan, T. S. (2014). Examining impacts of technostress on the professional salesperson's behavioural performance. Journal of Personal Selling and Sales Management, 34(1), 51-69. https://doi.org/10.1080/08853134.2013.870184

Tarafdar, M., Tu, Q., Ragu-Nathan, B. S., \& Ragu-Nathan, T. S. (2007). The impact of technostress on role stress and productivity. Journal of Management Information Systems, 24(1), 301-328. https://doi.org/10.2753/MIS0742-1222240109

Tarafdar, M., Tu, Q., Ragu-Nathan, T. S., \& Ragu-Nathan, B. S. (2011). Crossing to the dark side: Examining creators, outcomes, and inhibitors of technostress. Communications of the ACM, 54(9), 113-120. https://doi.org/10.1145/1995376.1995403

Ter Hoeven, C. L., van Zoonen, W., \& Fonner, K. L. (2016). The practical paradox of technology: The influence of communication technology use on employee burnout and engagement. Communication Monographs, 83(2), 239-263. https://doi.org/10.1080/03637751.2015.1133920

Valk, R., \& Hannon, S. B. T. (2017). Exploring job demands, job resources, personal resources and wellbeing of rotational assignees at hardship locations. Journal of Health, Safety and Environment, 33(2).

Van Steenbergen, E. F., Van Der Ven, C., Peeters, M. C. W., Taris, T. W., \& Steenbergen, E. F. Van. (2018). Transitioning Towards New Ways of Working: Do Job Demands, Job Resources, Burnout, and Engagement Change? Psychological Reports, 121(4), 736-766. https://doi.org/10.1177/0033294117740134

Verkijika, S. F. (2019). Digital textbooks are useful but not everyone wants them: The role of technostress. Computers and 140. https://doi.org/10.1016/j.compedu.2019.05.017

Wang, X., Tan, S. C., \& Li, L. (2020). Technostress in university students' technologyenhanced learning: An investigation from multidimensional person-environment misfit. Computers in Human Behavior, 105, 106208. https://doi.org/10.1016/j.chb.2019.106208

Xiao, L., \& Mou, J. (2019). Social media fatigue -Technological antecedents and the moderating roles of personality traits: The case of WeChat. Computers in Human Behavior, 101, 297-310. https://doi.org/10.1016/j.chb.2019.08.001

Ying, L. W., Xian, C. Y., Ye, C. C., Khie, L. S., Rozlan, S. B. M., Yong, W. J., \& Suki, N. M. (2021). YouTube for Procedural Learning: Empirical Insights on Student Intention to Use. In Handbook of Research on Technology Applications for Effective Customer Engagement (pp. 179-196). IGI Global.

Yu, T. K., Lin, M. L., \& Liao, Y. K. (2017). Understanding factors influencing information 
communication technology adoption behavior: The moderators of information literacy and digital skills. Computers in Human Behavior, 71, 196-208. https://doi.org/10.1016/j.chb.2017.02.005

Zainuddin, S., \& Isa, C. R. (2019). The role of workplace fairness and information sharing in a budget setting process: An empirical study. Gadjah Mada International Journal of Business, 21(2), 135-158. https://doi.org/10.22146/gamaijb.31133

Zainun, N. F. H., Johari, J., \& Adnan, Z. (2020). Technostress and Commitment to Change: The Moderating Role of Internal Communication. International Journal of Public Administration, 43(15), 1327-1339. https://doi.org/10.1080/01900692.2019.1672180

Zhang, S., Zhao, L., Lu, Y., \& Yang, J. (2016). Do you get tired of socializing? An empirical explanation of discontinuous usage behaviour in social network services. Information and Management, 53(7), 904-914. https://doi.org/10.1016/j.im.2016.03.006

Zhao, X., Xia, Q., \& Huang, W. (2020). Impact of technostress on productivity from the theoretical perspective of appraisal and coping processes. Information \& Management, 57(8), 103265. https://doi.org/10.1016/j.im.2020.103265

Zulfany, A. H., Dewi, R. S., \& Partiwi, S. G. (2019). Analyzing Mental Workload of Remote Worker by Using SWAT Methodology (Case Study: Remote Software Engineer). IOP Conference Series: Materials Science and Engineering, 598, 012008. https://doi.org/10.1088/1757-899X/598/1/012008 